\title{
Follicle and hormone dynamics in single versus double ovulating heifers
}

\author{
M P Palhao ${ }^{1,2}$, M A Beg $^{3}$, M T Rodrigues ${ }^{2}$ and O J Ginther ${ }^{1,3}$ \\ ${ }^{1}$ Eutheria Foundation, Cross Plains, Wisconsin 53528, USA, ${ }^{2}$ Departamento de Zootecnia, Universidade Federal de \\ Viçosa, 36570 Viçosa, Minas Gerais, Brazil and ${ }^{3}$ Department of Pathobiological Sciences, School of Veterinary \\ Medicine, University of Wisconsin-Madison, 1656 Linden Drive, Madison, Wisconsin 53706, USA
}

Correspondence should be addressed to O J Ginther at Eutheria Foundation, Department of Pathobiological Sciences, School of Veterinary Medicine, University of Wisconsin-Madison; Email: ginther@vetmed.wisc.edu

\begin{abstract}
Follicles $\geq 5 \mathrm{~mm}$ were ablated at 4 day post-ovulation in heifers to induce a follicular wave, and prostaglandin $F_{2 \alpha}$ was given at day 6 to increase the incidence of double ovulations. Follicle diameters and plasma hormone concentrations were compared between single ovulators $(n=12)$ and double ovulators $(n=8)$. In double ovulators, the interval from follicle deviation to the peak of the pre-ovulatory LH surge was shorter $(1.9 \pm 0.2$ vs $2.5 \pm 0.2$ days; $P<0.02)$ and diameter of the largest pre-ovulatory follicle was smaller $(12.2 \pm 0.5$ vs $13.3 \pm 0.3 \mathrm{~mm} ; \boldsymbol{P}<\mathbf{0 . 0 2}$ ). The $\mathrm{LH}$ concentrations of the pre-ovulatory surge did not differ between single and double ovulators for $24 \mathrm{~h}$ on each side of the peak. When data were normalised to LH peak, the peak of the pre-ovulatory FSH and oestradiol ( $\left.E_{2}\right)$ surges occurred in synchrony with the peak of LH surge for both groups. Concentration of FSH for $\mathbf{2 4} \mathrm{h}$ on each side of the peak showed a group effect $(P<0.0001)$ from lower concentration in the double ovulators. A group-by-hour interaction $(P<0.008)$ for $E_{2}$ reflected greater concentration in the double ovulators before and at the peak. Results indicated that two pre-ovulatory follicles resulted in an earlier and greater $\mathrm{E}_{2}$ increase, leading to lower FSH concentration, an earlier LH surge, and ovulation at a smaller diameter. In conclusion, the difference in hormone concentrations during the pre-ovulatory period was an effect rather than a cause of double ovulations.

Reproduction (2009) 138 561-570
\end{abstract}

\section{Introduction}

The selection of a dominant follicle during the oestrous cycle in cattle occurs during each of one or two anovulatory follicular waves and during the ovulatory wave (reviewed in Fortune et al. 2001, Ginther et al. 2003, Beg \& Ginther 2006, Webb \& Campbell 2007, Adams et al. 2008, Aerts \& Bols 2009, Mihm \& Evans 2008). Follicular growth in a wave is characterised by a 2 or 3 day common-growth phase after follicle emergence at $4.0 \mathrm{~mm}$. At the end of the commongrowth phase, usually one follicle continues to grow and becomes the developing dominant follicle and the remaining follicles (subordinates) regress. The end of the common-growth phase and the beginning of a distinctive difference in growth rates between the two largest follicles have been termed follicle deviation (Ginther et al. 1997) and, in cattle, occurs when the largest follicle reaches a mean diameter of $8.5 \mathrm{~mm}$ (Ginther et al. 1996).

On average, a transient elevation in $\mathrm{LH}$ begins before deviation and decreases after deviation (Kulick et al. 1999, Bergfelt et al. 2000, Ginther et al. 2001). The functional requirements of $\mathrm{F} 1$ for $\mathrm{LH}$ after deviation is indicated by a smaller diameter when LH is experimentally reduced (Ginther et al. 2001) and by cessation of growth beyond $9 \mathrm{~mm}$ when $\mathrm{LH}$ is suppressed (Gong et al. 1995). The dominant follicle acquires ovulatory capacity when it reaches about $10 \mathrm{~mm}$ (Sartori et al. 2001).

The deviation mechanism in monovulatory species including cattle allows one follicle to become dominant and ovulate. But occasionally, two or more follicles within the same wave become dominant, resulting in a phenomenon that has been termed codominance (Kulick et al. 2001, Beg et al. 2003, Acosta et al. 2005, Lopez et al. 2005). Induced follicle waves that developed codominant follicles have more follicles $\geq 4 \mathrm{~mm}$ but a similar interval from emergence to deviation and a similar diameter of two largest follicles at the beginning of deviation (Acosta et al. 2005). Codominant follicles may result in multiple ovulations but may also result in a single ovulation by undergoing two deviations (Kulick et al. 2001, Beg et al. 2003, Acosta et al. 2005). The first deviation occurs when the largest follicle is about $8.5 \mathrm{~mm}$ and is indicated by reduced growth of the third-largest follicle. The second deviation between the codominant follicles occurs 
36-50 $\mathrm{h}$ after the first deviation. The second deviation is associated temporally with a more precipitous decrease in FSH after the beginning of the first deviation. The incidence of spontaneous codominance in Holstein heifers during the first wave of the oestrous cycle (wave 1) has been reported as 28\% (Beg et al. 2003) and 35\% (Kulick et al. 2001) and in Holstein cows as 40\% (Lopez et al. 2005). Spontaneous codominant follicles were associated with greater $\mathrm{FSH}$ and $\mathrm{LH}$ concentrations before deviation and a greater reduction in $\mathrm{FSH}$ after the beginning of deviation in heifers (Kulick et al. 2001) and cows (Lopez et al. 2005). The oestradiol $\left(E_{2}\right)$ concentration was higher after deviation for double-dominant versus single-dominant heifers (Kulick et al. 2001) and cows (Lopez et al. 2005).

The incidence of spontaneous multiple ovulations in Holstein heifers has been reported as 1-4\% (Wiltbank et al. 2000) and in cows as 15-28\% (Lopez-Gatius et al. 2005, Mann et al. 2007) and up to $40 \%$ in highproducing dairy cows (Wiltbank et al. 2000). Temporal relationships between the gonadotropin concentrations and spontaneous multiple ovulations in dairy cattle have not been reported. In one study of single versus multiple ovulations (Mann et al. 2007), no significant difference in plasma concentrations of $E_{2}$ around the time of ovulation was found. In another series of studies (Echternkamp et al. 1990, 2004), cows were genetically selected for double ovulations and twin births (defined as twinners) and were compared with controls at $0,1,2$, and 3 days after induction of luteolysis with prostaglan$\operatorname{din} \mathrm{F}_{2 \alpha}\left(\mathrm{PGF}_{2 \alpha}\right)$. Cows were slaughtered on the indicated days, precluding determination of ovulation rate or normalising to ovulation or to the $\mathrm{LH}$ surge. No differences were found after $\mathrm{PGF}_{2 \alpha}$ treatment between the twinner and control cows in follicular-fluid concentration of ovarian steroids or in plasma concentration of $\mathrm{LH}$ and $\mathrm{FSH}$. In mares, it was concluded that a preovulatory difference in hormone concentrations between single and double ovulations was an effect rather than a cause of double ovulations (Ginther et al. 2008, 2009).

A $75 \%$ incidence of codominance occurred in Holstein heifers after ablation of all follicles $\geq 5 \mathrm{~mm}$ 4 days after ovulation, compared with $25 \%$ in controls and in groups with follicle ablation on other days (Acosta et al. 2005). The greater rate of codominance was associated with a more prominent $\mathrm{FSH}$ surge after follicle ablation on day 4 when FSH concentrations were low. The experiment was done during the anovulatory wave 1 , and the codominant follicles did not result in double ovulations. The luteal phase was terminated by $\mathrm{PGF}_{2 \alpha}$ treatment 4 days after expected deviation, which was apparently too late for ovulation by the dominant follicles. In this regard, aspiration of all follicles $\geq 5 \mathrm{~mm} 6.4$ days after ovulation followed by administration of $\mathrm{PGF}_{2 \alpha} 1.5$ days later resulted in $54 \%$ double-ovulation rate in beef cows (Mussard et al. 2007).
There apparently have been no published reports in cattle on the pre-ovulatory temporal relationships between follicle development and plasma gonadotropin concentrations in association with single versus double ovulations. The present experiment used follicle ablation on day 4 and $\mathrm{PGF}_{2 \alpha}$ administration on day 6 for increasing the incidence of double ovulations in heifers. The objective was to compare follicle growth and plasma hormone concentrations associated with single versus double ovulations.

\section{Results}

The number of heifers with single and multiple dominant follicles and the number with multiple dominant follicles that developed multiple ovulations are shown (Fig. 1). In the 22 single ovulators, data were not available for seven heifers and three heifers were not used, owing to three dominant follicles, non-response to $\mathrm{PGF}_{2 \alpha,}$ or delayed emergence of the induced follicular wave. One heifer with three ovulations was excluded from the nine heifers with multiple ovulations. Thus, 12 singles ovulators and 8 double ovulators were compared in the statistical analyses. Ovulations in double ovulators were synchronised within $6 \mathrm{~h}$ in 6 out of 8 heifers, whereas in the remaining two the second ovulation occurred from F2 at 12 or $36 \mathrm{~h}$ after ovulation from F1. Double ovulations occurred in the same ovary in 4 out of 8 heifers and in each ovary in 4 out of 8 heifers.

\section{Single versus double ovulators}

There was no difference $(P<0.05)$ between groups in the number of follicles ablated on day 4 . The interval from ablation to emergence and emergence to deviation did not differ between single and double ovulators (Table 1).

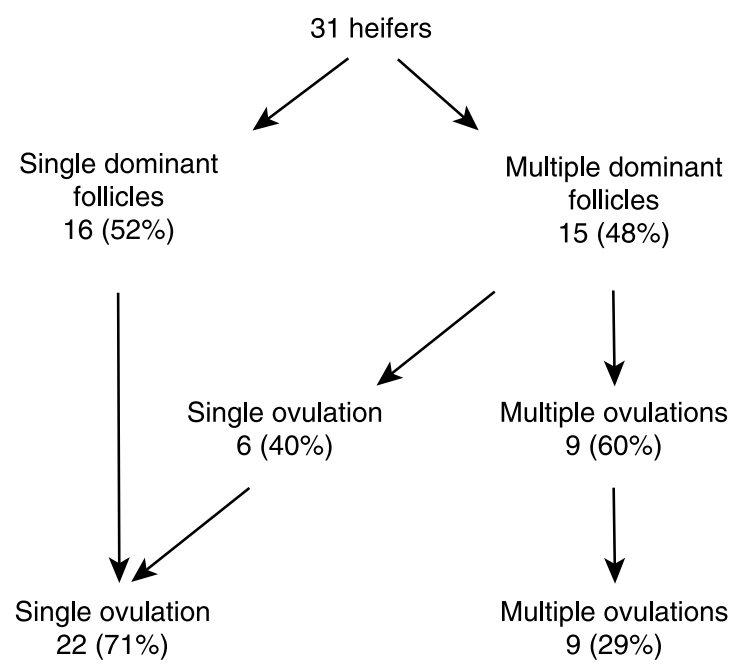

Figure 1 Diagramatic outcome for single and multiple dominant follicles and single and multiple ovulations after ablating all follicles $(\geq 5 \mathrm{~mm})$ and treatment with $\mathrm{PGF}_{2 \alpha}$. 
Table 1 Mean \pm s.E.M. for intervals between follicle events in single and double ovulators ${ }^{\mathrm{a}}$.

\begin{tabular}{lccc}
\hline Interval & Single ovulators $(n=12)$ & Double ovulators $(n=8)$ & Probability \\
\hline Ablation to emergence (days) & $1.2 \pm 0.1$ & $1.3 \pm 0.2$ & $\mathrm{NS}$ \\
Emergence to deviation (days) & $2.4 \pm 0.1$ & $2.4 \pm 0.1$ & $\mathrm{NS}$ \\
Deviation to max. diam. F1 (days) & $3.1 \pm 0.2$ & $2.4 \pm 0.3$ & \\
Deviation to LH peak (days) & $2.5 \pm 0.2$ & $1.9 \pm 0.2$ & \\
Deviation to ovulation (days) & $3.9 \pm 0.2$ & $3.3 \pm 0.1$ & \\
LH peak to ovulation (h) & $33.5 \pm 0.9$ & $32.2 \pm 1.9$ & \\
Max. diam. F1 to ovulation (h) & $19.5 \pm 2.6$ & $19.5 \pm 2.2$ & $\mathrm{P}<0.02$ \\
Ovulation to ovulation (days) & $12.2 \pm 0.2$ & $11.7 \pm 0.2$ & $\mathrm{NS}$ \\
\end{tabular}

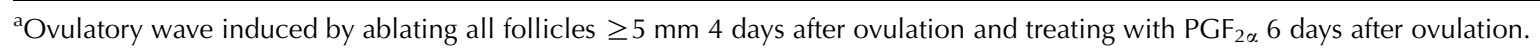

In addition, the day of emergence and deviation, diameter at emergence and deviation, and follicle growth rate between emergence and deviation did not differ between groups for either F1 or F2 (not shown). The interval from deviation to maximum diameter of $\mathrm{F} 1$, to the peak of the $\mathrm{LH}$ surge, and to ovulation was significantly shorter in the double ovulators than in the single ovulators. A reduction in the interval from the pretreatment to post-treatment ovulation in double ovulators approached significance. The diameter of F1 and F2 at deviation was not different between the single and double ovulators (Table 2). The diameter of F1 (largest ovulatory follicle) was greater and the diameter of F2 was less in the single ovulators than in the double ovulators at maximum diameter, at the peak of the $\mathrm{LH}$ surge, and at preovulation of $\mathrm{F} 1$. The growth rate of $\mathrm{F} 1$ between deviation and the $\mathrm{LH}$ peak (combined for groups, $1.8 \pm 0.1 \mathrm{~mm} /$ day) and between the $\mathrm{LH}$ peak and preovulation $(0.1 \pm 0.1 \mathrm{~mm} /$ day $)$ were not different between single and double ovulators.

Data and results of the analyses for diameters of $\mathrm{F} 1$, $\mathrm{F} 2$, and F3 normalised to deviation and to the $\mathrm{LH}$ peak are shown (Fig. 2). When normalised to deviation, only the main effect of hour, representing a gradual diameter increase, was significant for each follicle. For F1 normalised to the LH peak, the hour effect was

Table 2 Mean \pm S.E.M. diameters of F1 and F2 in single and double ovulators $^{\mathrm{a}}$.

\begin{tabular}{lccl}
\hline Diameter $(\mathrm{mm})$ & $\begin{array}{c}\text { Single ovulators } \\
(n=12)\end{array}$ & $\begin{array}{c}\text { Double ovulators } \\
(n=8)\end{array}$ & Probability \\
\hline At deviation & & & \\
F1 & $8.9 \pm 0.2$ & $8.8 \pm 0.2$ & $\mathrm{NS}$ \\
F2 & $8.3 \pm 0.2$ & $8.3 \pm 0.3$ & $\mathrm{NS}$ \\
At maximum & & & \\
F1 & $13.9 \pm 0.3$ & $12.3 \pm 0.5$ & $P<0.004$ \\
F2 & $9.5 \pm 0.2$ & $11.4 \pm 0.3$ & $P<0.0001$ \\
At peak of LH surge & & & \\
F1 & $13.3 \pm 0.3$ & $12.2 \pm 0.5$ & $P<0.02$ \\
F2 & $8.9 \pm 0.3$ & $11.1 \pm 0.4$ & $P<0.0001$ \\
At preovulation of F1 & & & \\
F1 & $13.5 \pm 0.3$ & $12.0 \pm 0.6$ & $P<0.01$ \\
F2 & $8.6 \pm 0.4$ & $10.8 \pm 0.4$ & $P<0.0005$ \\
\hline
\end{tabular}

a Ovulatory wave induced by ablating all follicles $\geq 5 \mathrm{~mm} 4$ days after ovulation and treating with $\mathrm{PGF}_{2 \alpha} 6$ days after ovulation. significant, representing increasing diameter averaged over groups. The group effect was also significant, owing to a greater diameter in the single ovulators, averaged over hours. For F2 normalised to the LH peak, the main effects of group and hour and their interaction were significant. These effects were attributable to a greater average diameter with a greater increase in diameter before than after the $\mathrm{LH}$ peak in the double ovulators. There were no significant differences for F3 normalised to the $\mathrm{LH}$ peak.

Normalised to the beginning of deviation, there were no significant effects for $\mathrm{LH}$, but a main effect of hour for FSH represented declining concentrations (Fig. 3). Although the interaction for FSH was not significant, a decrease during $12-24 \mathrm{~h}$ after deviation was significant $(P<0.05)$ only for the double ovulators. A lower concentration in the double than in the single ovulators at $24 \mathrm{~h}$ approached significance $(P<0.06)$. For $\mathrm{LH}, \mathrm{FSH}$, and $E_{2}$ concentrations normalised to the peak of $\mathrm{LH}$, there was a main effect of hour for each hormone. The means for the pre-ovulatory peaks of $\mathrm{LH}, \mathrm{FSH}$, and $\mathrm{E}_{2}$ occurred synchronously among hormones for both single and double ovulators when data were normalised to the $\mathrm{LH}$ peak. Both the first and second nadirs were synchronous between concentrations of $\mathrm{LH}$ and $\mathrm{FSH}$. In addition to the hour effect for each hormone, a group effect was detected for FSH and an interaction for $\mathrm{E}_{2}$. Differences between $\mathrm{FSH}$ and $\mathrm{LH}$ resulted from an $\mathrm{FSH}$ increase beginning at the second nadir and represented the beginning of the periovulatory surge. In addition, a group effect for $\mathrm{FSH}$ resulted from a greater concentration averaged over hours combined for both surges in single than in double ovulators $(0.25 \pm 0.01$ vs $0.22 \pm 0.02 \mathrm{ng} / \mathrm{ml}$ ). The interaction for $E_{2}$ represented a more prominent increase in the double than in single ovulators, with greater concentration in the double ovulators at $-12 \mathrm{~h}(P<0.06)$ and $-6 \mathrm{~h}(P<0.03)$ before the peak and at the peak $(P<0.01)$.

The hour of the periovulatory peak in FSH concentration was not significantly different between single and double ovulators $(35.0 \pm 3.3$ and $32.3 \pm 2.8 \mathrm{~h}$ after peak $\mathrm{LH}$ respectively; not shown). The concentration at the periovulatory peak also was similar between single and double ovulators $(0.49 \pm 0.03$ vs $0.44 \pm 0.04 \mathrm{ng} / \mathrm{ml})$. 


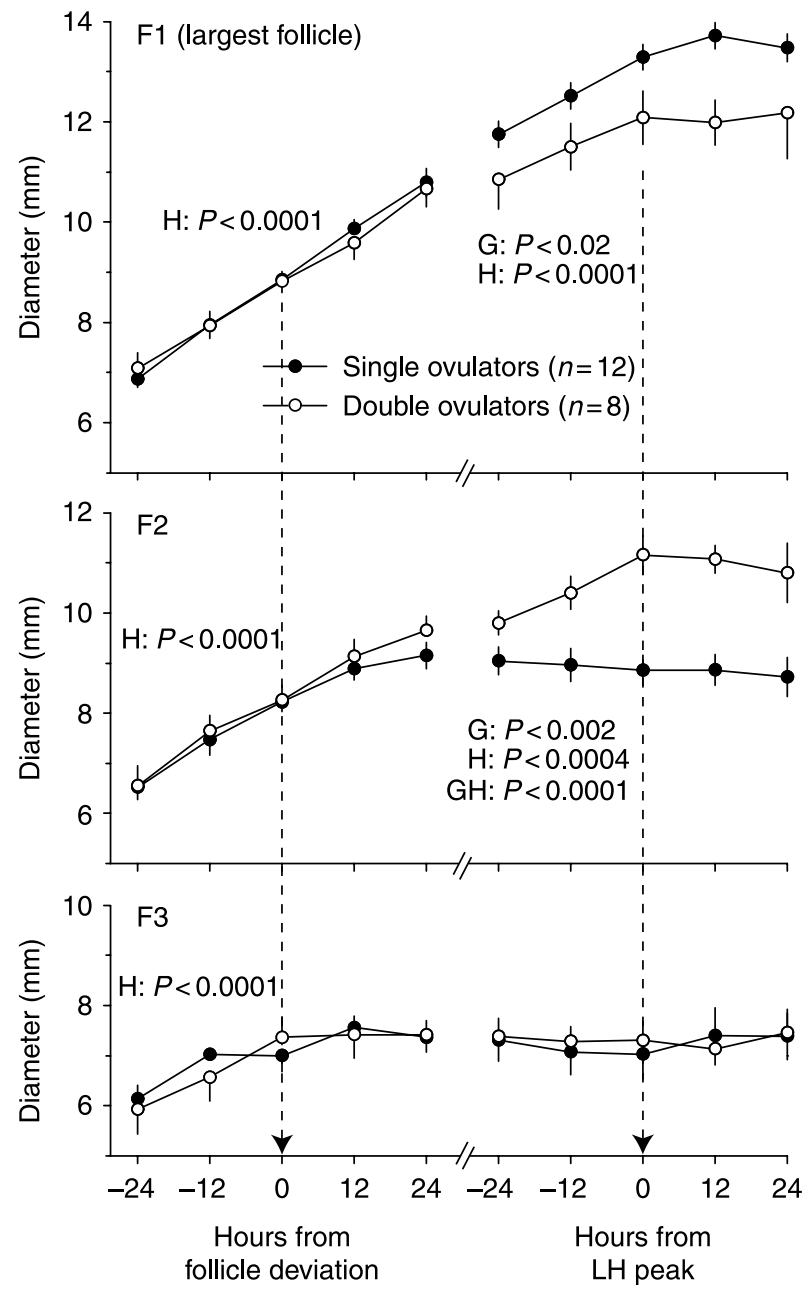

Figure 2 Mean ( \pm S.E.M.) for diameters of the three largest follicles (F1, F2, and F3) in single and double ovulators. Significant main effects of group $(\mathrm{G})$ and hour $(\mathrm{H})$ and an interaction $(\mathrm{GH})$ are shown for $24 \mathrm{~h}$ before to $24 \mathrm{~h}$ after the beginning of follicle deviation and for $24 \mathrm{~h}$ before to $24 \mathrm{~h}$ after the peak of the preovulatory $\mathrm{LH}$ surge.

\section{Single versus double dominant follicles in single ovulators}

In the single-ovulating group, the length of the interovulatory period and the growth of F1 were not different between subgroups with one versus two dominant follicles (not shown). Concentration of $\mathrm{LH}$ did not differ between subgroups when data were normalised either to deviation or to the $\mathrm{LH}$ peak (not shown). For F2, a significant hour effect normalised to deviation reflected growth of the follicle averaged over subgroups (Fig. 4). A significant interaction of subgroup and hour for $\mathrm{F} 2$ reflected a constant diameter increase for $12 \mathrm{~h}$ before and $24 \mathrm{~h}$ after deviation in the doubledominant subgroup and a reduced diameter increase after deviation in the single-dominant subgroup. As a result, F2 was smaller $(P<0.002)$ in the single-dominant subgroup $(8.8 \pm 0.2 \mathrm{~mm})$ than in the double-dominant subgroup $(10.3 \pm 0.4 \mathrm{~mm}) 24 \mathrm{~h}$ after deviation. The only significant difference between the single- and doubledominant subgroups normalised to the $\mathrm{LH}$ peak was a greater diameter of F2 in the double-dominant subgroup throughout the period, as indicated by a significant group effect without an interaction.

The main effect of hour for FSH normalised to deviation was significant, resulting from a continuing decrease averaged over subgroups (Fig. 4). However, the interaction was also significant, reflecting greater concentrations before deviation and $6 \mathrm{~h}$ after deviation

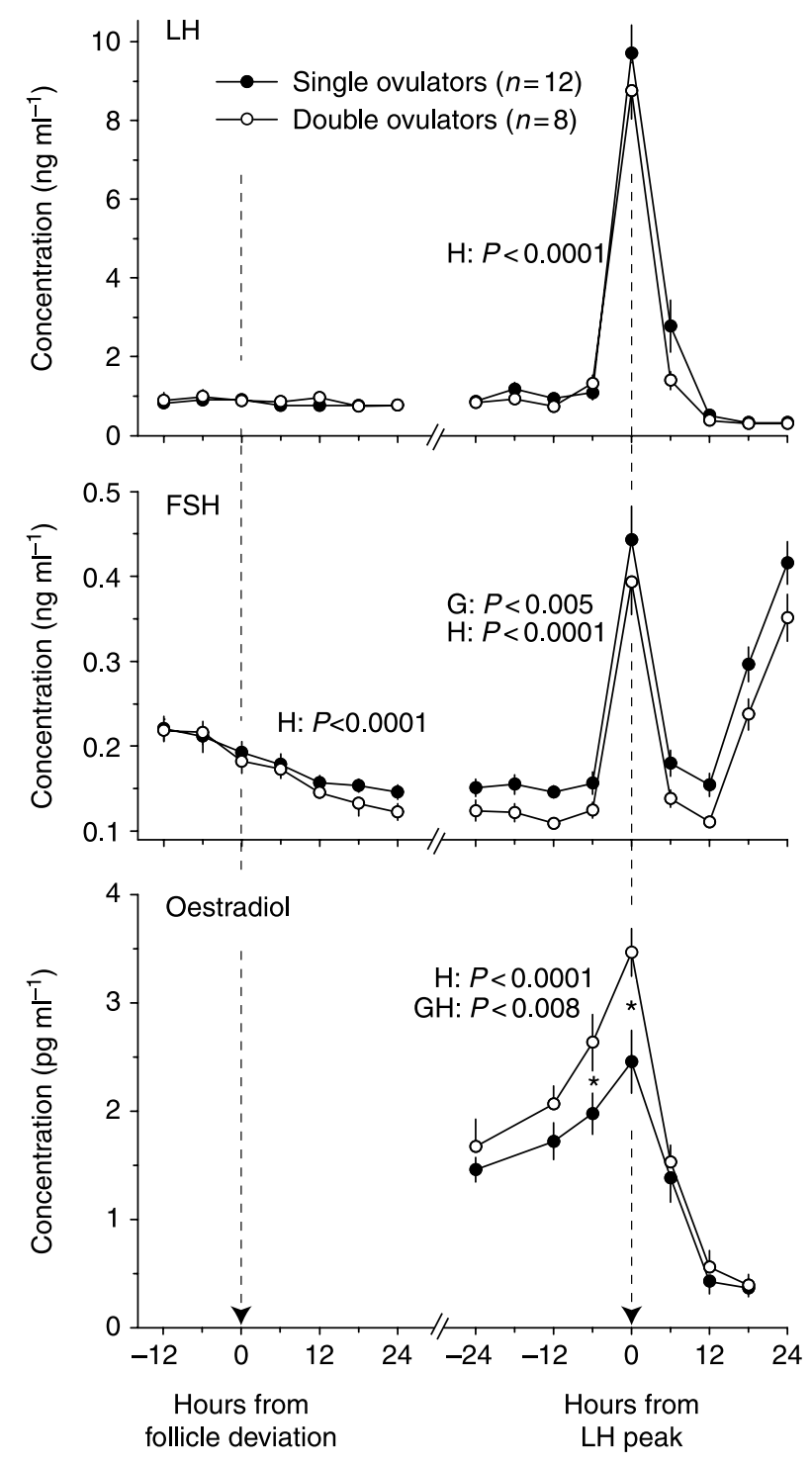

Figure 3 Mean ( \pm s.E.M.) for concentrations of $\mathrm{LH}, \mathrm{FSH}$, and oestradiol in single and double ovulations. Significant main effects of group (G) and hour $(\mathrm{H})$ and an interaction $(\mathrm{GH})$ are shown for $12 \mathrm{~h}$ before to $24 \mathrm{~h}$ after the beginning of follicle deviation and for $24 \mathrm{~h}$ before to $24 \mathrm{~h}$ after the peak of the preovulatory $\mathrm{LH}$ surge for $\mathrm{LH}$ and $\mathrm{FSH}$ and $24 \mathrm{~h}$ before to $20 \mathrm{~h}$ after peak of preovulatory LH surge for oestradiol. An asterisk indicates a difference $(P<0.05)$ between groups when a significant interaction was obtained. 


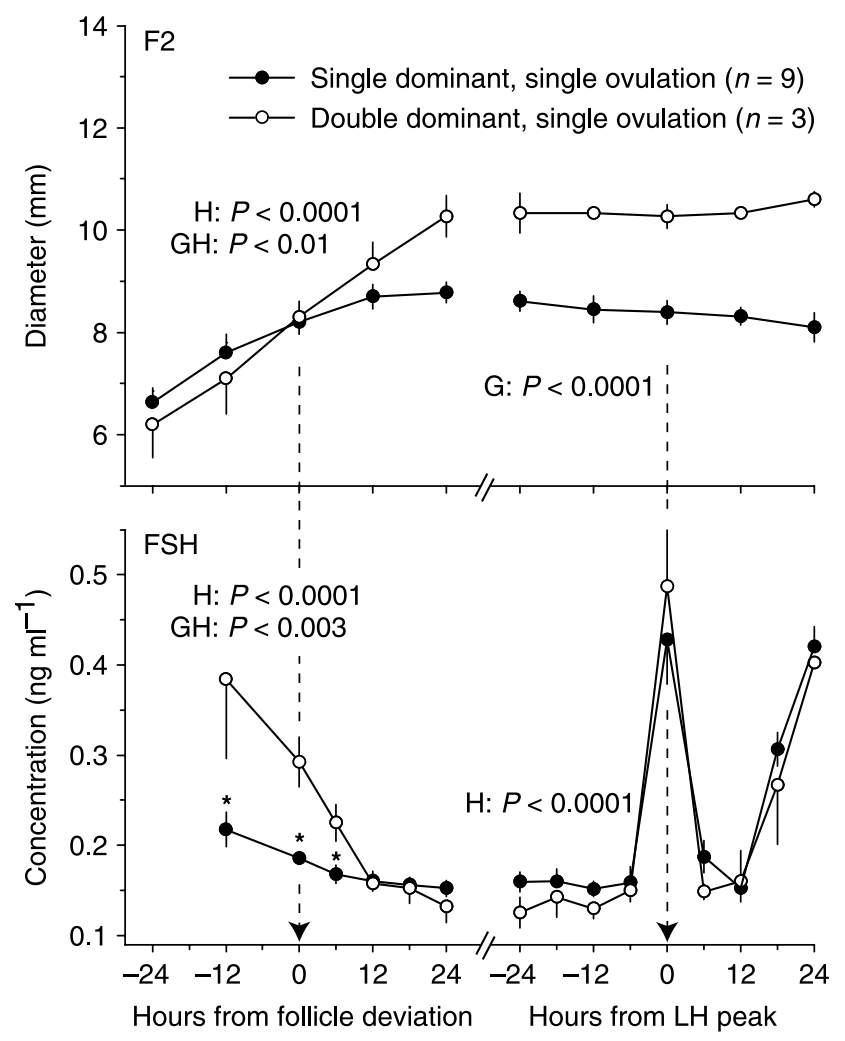

Figure 4 Mean ( \pm S.E.M.) for diameter of F2 and concentration of FSH in single ovulators with single and codominant follicles. Significant main effects of group $(\mathrm{G})$ and hour $(\mathrm{H})$ and an interaction $(\mathrm{GH})$ are shown for $12 \mathrm{~h}$ before to $24 \mathrm{~h}$ after the beginning of follicle deviation and for $24 \mathrm{~h}$ before and $24 \mathrm{~h}$ after the peak of the pre-ovulatory LH surge. An asterisk indicates a difference $(P<0.05)$ between groups when a significant interaction was obtained.

in the double-dominant subgroup, with no difference thereafter. Concentrations of FSH were not different between single and double ovulators normalised to the LH peak.

\section{Discussion}

It is not practical to use natural ovulations in Holstein heifers to study the temporal relationships between follicles and hormones associated with single versus multiple ovulations, owing to the low natural incidence of multiple ovulations. In the contemporary heifers that served as the source of the heifers for the present study, the natural incidence was $1.5 \%$ ( 1 out of 67 oestrous cycles). Follicle ablation during the nadir in FSH concentrations between the surges that stimulate waves 1 and 2 (Kulick et al. 2001) was used to increase the incidence of multiple ovulations without the use of exogenous gonadotropins. An increased incidence of multiple dominant follicles and multiple ovulations in the present day- 4 ablation model agrees with the results of ablating on days 4, 5 or 6 (Gibbons et al. 1997,
Acosta et al. 2005, Mussard et al. 2007). Days 4-6 approximate the reported period of low FSH concentrations between FSH surges (Kulick et al. 2001).

The concentrations of FSH were not determined immediately post-ablation in the present study. However, a previous study indicated that ablation of the follicles of wave 1 during the FSH nadir removed the $\mathrm{FSH}$ suppression and was followed by an $\mathrm{FSH}$ surge more prominent than a natural surge (Acosta et al. 2005). An increased number of follicles during the common-growth phase of the induced wave and an increased incidence of multiple dominant follicles were attributed to the prominent FSH surge. Greater pre-deviation concentrations of $\mathrm{LH}$ and $\mathrm{FSH}$ and lesser post-deviation concentrations of FSH occurred during codominance in the ablation model (Acosta et al. 2005) and in naturally occurring codominance (Kulick et al. 2001, Lopez et al. 2005). Greater concentrations of $\mathrm{E}_{2}$ were associated with the $\mathrm{LH}$ surge of the double ovulators in the present study and $\sim 2$ days after the beginning of deviation in natural codominance (Kulick et al. 2001). Apparently, follicle and hormone dynamics during the ovulatory period were similar between double ovulations in the follicle-ablation model and in natural double ovulations.

The frequency of conversion of natural double dominants to double ovulations apparently has not been studied in cattle in the same experiment. The lack of information is attributable to use of anovulatory wave 1 in most wave characterisation studies, without an associated induction of luteolysis. The natural doubleovulation rate is low (about 2\%) in both heifers (Wiltbank et al. 2000) and ponies (Ginther 1992). In Holstein heifers, the incidence of double dominants during natural ovulatory waves has been reported as $10 \%$ (Kulick et al. 2001). In pony mares, two dominant follicles developed in $34 \%$ of natural ovulatory waves, but conversion to double ovulatory follicles occurred in only $9 \%$ of mares with double dominants (Jacob et al. 2009). These results indicate that the incidence of conversion of natural double dominants to double ovulations is low in both species. A high conversion rate $(60 \%)$ of double dominant follicles to double ovulations was found in the present study in heifers for ovulatory waves that were induced by ablation and $\mathrm{PGF}_{2 \alpha}$ administration. In ponies, both dominant follicles ovulated more frequently in the induced waves than in the natural waves (Ginther et al. 2008). These results of both species indicate that waves induced by a combination of ablation and $\mathrm{PGF}_{2 \alpha}$ treatment have more dominant follicles and a higher conversion rate of the double dominant follicles to double ovulations than for natural waves.

The role of the induction of luteolysis 2 days after follicle ablation on the increased double-ovulation rate was not studied. The decrease in progesterone from the $\mathrm{PGF}_{2 \alpha}$ treatment may have allowed an $\mathrm{LH}$ 
increase while the follicles were still in their commongrowth phase, owing to the loss of the negative effect of progesterone on LH (Ginther et al. 2001). However, concentrations of $\mathrm{LH}$ during the common-growth phase were not adequately considered in the present study, owing to the availability of blood samples only for $12 \mathrm{~h}$ before the beginning of deviation. In mares, an increase in LH concentrations during the commongrowth phase is associated with an increase in double ovulations (Ginther et al. 2009) and treatment with $\mathrm{PGF}_{2 \alpha}$ during dioestrus increases the incidence of double ovulations (Ginther \& Almamun 2009). These results in mares indicate a need for similar studies in heifers, i.e. the increased double-ovulation rate in the present study in heifers may not be entirely a result of a more prominent postablation FSH surge.

In horses (Ginther et al. 2008, 2009) and sheep (McNatty et al. 1984), the pre-ovulatory diameter of each ovulatory follicle in double ovulators is less than for single ovulators. Similar information apparently has not been available for cattle, but it has been reported that each corpus luteum is smaller for two corpora lutea than for one corpus luteum (Mann et al. 2007). In the present study, diameter of F1 was about $1.5 \mathrm{~mm}$ smaller in double ovulators than in single ovulators and in double ovulators $\mathrm{F} 2$ was about $1 \mathrm{~mm}$ smaller than F1 both at maximum diameter and $12 \mathrm{~h}$ before ovulation (preovulatory). The greater diameter of $\mathrm{F} 1$ in single versus double ovulators began within 1 day before the LH peak or about 2.5 days before ovulation. The corresponding diameter differences in mares also became apparent within 2.5 days before ovulation (Ginther et al. 2009). The interval from wave emergence to deviation was not different between single and double ovulators in heifers (present study) and mares (Ginther et al. 2008), but the interval from deviation to ovulation was shorter in double ovulators in heifers (significant) and in mares (approached significance). In the heifers, the shorter interval from deviation to ovulation in the double ovulators accounted for the smaller F1 in that the growth rate of F1 did not differ between groups. These results indicate that in dairy heifers (present study) and in mares (Ginther et al. 2008) the relationships of follicle diameter to double ovulation are evident only after deviation. Furthermore, the interval from deviation to the LH peak was shorter in the double-ovulating heifers, indicating that the smaller pre-ovulatory diameter was at least partially a function of an earlier LH surge. The earlier LH surge in double ovulators may reflect the earlier and greater increase in $E_{2}$ by the double follicles. In this regard, exogenous $E_{2}$ induces a $\mathrm{LH}$ surge in ovariectomised and ovarian-intact cattle (Hobson \& Hansel 1972, Engelhardt et al. 1989). The diameter of F2 in the double ovulators ranged from 9.1 to $12.0 \mathrm{~mm}$ at the peak of the LH surge; two follicles $(25 \%)$ were $<11 \mathrm{~mm}$. This result seems consistent with the conclusion that ovulatory capacity is acquired at about $10 \mathrm{~mm}$, based on inducing ovulation by exogenous LH at various diameters (Sartori et al. 2001).

The maximum concentrations of $\mathrm{E}_{2}$ and $\mathrm{FSH}$ in the pre-ovulatory surges occurred at the peak of the LH surge for both single and double ovulators. The close temporal relationship between the three hormones has been previously reported for single ovulators (Bergfelt et al. 1997, Haughian et al. 2004). An apparently unreported observation in cattle was a reduction or cessation in the diameter increase for $\mathrm{F} 1$ in both single and double ovulators and for F2 in double ovulators beginning at the synchronised $\mathrm{LH}, \mathrm{FSH}$ and $\mathrm{E}_{2}$ peaks. On a temporal basis, the decreases in $\mathrm{LH}, \mathrm{FSH}$ or $\mathrm{E}_{2}$ after the peak concentrations could have been related to or involved in the reduction in follicle growth beginning about $33 \mathrm{~h}$ before ovulation. A similar cessation or reduction in follicle growth occurs in mares 2 days before ovulation in synchrony with the peak of the pre-ovulatory $E_{2}$ surge, but both $\mathrm{LH}$ and $\mathrm{FSH}$ continue to increase until after ovulation (Ginther et al. 2009). Therefore, on a species comparative basis, the reduction in follicle growth and the beginning of an $E_{2}$ decrease apparently represent the same mechanism. The reduction in follicle growth in mares has been attributed to the attainment of a critical level of $\mathrm{LH}$, based on an immediate cessation of growth and an $E_{2}$ reduction when an ovulatory dose of hCG is given (Gastal et al. 2006). In heifers, a similar critical level of LH may be reached during the LH surge. The molecular basis for an apparent negative effect of a critical level of LH in blocking $\mathrm{E}_{2}$ production by downregulation of aromatase and other steroidogenic enzymes in horses and cattle has been discussed (Gastal et al. 2006).

The LH concentrations were similar between single and double ovulators at the LH surge. Also in mares, the preovulatory concentrations of LH were not different between single and double ovulators (Ginther et al. 2008, 2009). Lower FSH concentrations in doubleovulating heifers seemed to begin $24 \mathrm{~h}$ after deviation. The lower FSH in double ovulators continued throughout the $24 \mathrm{~h}$ before and $24 \mathrm{~h}$ after the peaks of the preovulatory $\mathrm{LH} / \mathrm{FSH}$ surges. This conclusion relies statistically on the main effect of group without a detected group-by-hour interaction. The lower FSH was temporally associated with greater $\mathrm{E}_{2}$ concentrations before and at the peak of the FSH surge. A similar FSH/ $\mathrm{E}_{2}$ relationship occurs in double-ovulating mares during the pre-ovulatory period (Ginther et al. 2008, 2009). The greater plasma $E_{2}$ in the two species is attributable to the presence of two pre-ovulatory follicles in the double ovulators. A negative effect of exogenous $\mathrm{E}_{2}$ on $\mathrm{FSH}$ has been shown in heifers (Miller et al. 1981). In the present study, $E_{2}$ concentration was not different between single and double ovulators after the peak of the pre-ovulatory surge, but FSH continued to be lower after the peak of the pre-ovulatory FSH surge and during the ascending portion of the periovulatory surge. 
The reason for the apparent continuation of the lower concentrations of FSH in the double ovulators after the pre-ovulatory peak is not known, but may be a consequence of the earlier establishment of reduced concentrations.

The greater $\mathrm{LH}$ and FSH concentrations that have been reported before and at deviation in cattle that developed double dominant follicles (Kulick et al. 2001, Acosta et al. 2005, Lopez et al. 2005) were not detected during the $12 \mathrm{~h}$ before deviation in the present study. A major difference between the reported studies and the present study was that the outcome (ovulation or atresia) of each of the double dominant follicles was not determined in the reported studies and presumably would have included follicles that would and would not have ovulated. The high levels of FSH before deviation in cattle that later develop multiple dominant follicles seems consistent with reports in women. Women with a history of giving birth to spontaneous twins have higher FSH concentrations than in controls during the portion of the menstrual cycle when follicles are recruited (Lambalk et al. 1998). By contrast, mares with multiple dominant follicles had lower concentrations of FSH before deviation (Ginther et al. 2008); the enhanced FSH suppressing effect of multiple follicles was attributed to greater predeviation inhibin output. The role of inhibin in the $\mathrm{FSH}$ reduction at deviation and at ovulation was not determined in the present study, owing to the unavailability of inhibin antigen. In this regard, both inhibin and $E_{2}$ increase during days 3-9 of the bovine oestrous cycle (Martin et al. 1991), which is expected to encompass deviation. In Holstein cows, double and triple dominant follicles were associated with greater $\mathrm{FSH}$ and lower immunoreactive-inhibin concentrations $24-12 \mathrm{~h}$ before the beginning of deviation than for single dominant follicles (Lopez et al. 2005). Inhibin-A concentrations were low on the day of ovulation (Bleach et al. 2001).

Comparisons were also made between subgroups with single and double dominant follicles within the single-ovulating group. This has not been done previously. No significant effects were found on diameter of F1 and concentration of $\mathrm{LH}$ either by normalisation to deviation or to the LH peak. The diameter of F2 was greater in the single ovulators with two dominant follicles than with one dominant follicle by $24 \mathrm{~h}$ after the beginning of deviation and then remained at approximately the same diameter until $24 \mathrm{~h}$ after the $\mathrm{LH} / \mathrm{FSH}$ preovulatory peak. Thus, the presence of the large anovulatory F2 during the pre-ovulatory period did not alter the gonadotropin concentrations and morphologic regression of F2 did not occur despite great fluctuations in concentrations of each gonadotropin. The most pronounced difference between subgroups was the greater $\mathrm{FSH}$ concentrations before and at the beginning of deviation in the double-dominant subgroup. This is consistent with the results of previous comparisons between heifers with single and double dominant follicles when the outcome of the double dominant follicles was unknown (Kulick et al. 2001, Acosta et al. 2005). In the present study, the greater FSH concentrations near the beginning of deviation occurred when only one follicle of double dominant follicles ovulated, but not when both follicles ovulated. Although interesting, reservation on this difference between double dominants with single versus double ovulations is recommended because of the small number $(n=3)$ of double dominants with a single ovulation.

In conclusion, an increased incidence of double dominant follicles and double ovulations was induced by ablation of follicles $\geq 5 \mathrm{~mm}$ during the nadir in FSH concentrations between FSH surges, followed in 2 days by administration of $\mathrm{PGF}_{2 \alpha}$. The interval from follicle deviation to the peak of the pre-ovulatory $\mathrm{LH}$ surge was shorter and the diameter of the pre-ovulatory follicles at the peak of the surge was smaller in double ovulators. Diameter of the pre-ovulatory follicles did not increase between the LH peak and ovulation. When data were normalised to the LH peak, the peak of the preovulatory $\mathrm{FSH}$ and $\mathrm{E}_{2}$ surges occurred in synchrony with the $\mathrm{LH}$ peak in both single and double ovulators. Concentration of LH from $24 \mathrm{~h}$ before to $24 \mathrm{~h}$ after the peak did not differ between single and double ovulators, but the concentration of $E_{2}$ was greater and concentration of $\mathrm{FSH}$ was lower in the double ovulators. The interpretation was that the presence of two preovulatory follicles resulted in an earlier and greater $\mathrm{E}_{2}$ concentration which led to lower FSH concentration, an earlier appearance of the $\mathrm{LH}$ surge, and ovulation of a smaller follicle.

\section{Material and Methods}

\section{Animals and ultrasonography}

A total of 31 Holstein heifers aged 12-18 months and weighting $330-575 \mathrm{~kg}$ were used. All heifers had a single ovulation during the previous oestrous cycle with at least two cycles of 16-24 days. The heifers did not have apparent abnormalities of the reproductive tract, based on transrectal ultrasound examinations (Ginther 1998) and were acclimated to the handling procedures for at least 2 weeks prior to the experiment. Heifers remained healthy and had good body condition throughout the experiment. The feeding program consisted of access to a mixture of grass and alfalfa hay, water and minerals with grain supplementation ad libitum. Animals were handled in accordance with the United States Department of Agriculture Guide for Care and Use of Agricultural Animals in Research.

A duplex B-mode (grey scale) and pulsed-wave colourDoppler ultrasound instrument (Aloka SSD 3500; Aloka American, Wallingford, CT, USA) equipped with a lineararray 7.5-MHz transducer was used. Transrectal scanning of the ovaries for measurement of follicles, detecting ovulation and determining the cross-sectional area of the corpus luteum was 
done as described (Ginther 1998). Heifers were checked once daily for ovulation beginning when a pre-ovulatory follicle was present. The day of ovulation was designated day 0. Follicle ablations were done by ultrasound-guided transvaginal aspiration of follicle contents, using a 17-ga needle connected to a vacuum pump as described (Bergfelt et al. 1994, Bodensteiner et al. 1996). Any follicle site that refilled with a fluid collection of $\geq 5 \mathrm{~mm} 24 \mathrm{~h}$ later was aspirated again. If needed for generation of optimal ultrasound images, heifers were sedated during scanning with xylazine hydrochloride $(0.05 \mathrm{mg} / \mathrm{kg}$, i.m.; Xila-ject, Phoenix Pharmaceutical, Inc., St Joseph, MO, USA) as described previously (Araujo \& Ginther 2009).

\section{Experimental design}

On day 4 , all follicles $\geq 5 \mathrm{~mm}$ in both ovaries were ablated to induce a surge of $\mathrm{FSH}$ that was expected to stimulate an increased incidence of codominant follicles (Acosta et al. 2005). Beginning on day 5, the three largest follicles of the induced wave were scanned twice a day, and follicle identity was maintained from examination-to-examination as described (Pierson \& Ginther 1988, Sirois \& Fortune 1988). Scanning every $12 \mathrm{~h}$ continued until $36 \mathrm{~h}$ after the next ovulation. The heifers received two injections of $\mathrm{PGF}_{2 \alpha}$ (25 mg; Lutalyse; Pfizer Animal Health, New York City, NY, USA) $12 \mathrm{~h}$ apart on day 6 to terminate the luteal phase. Blood samples were taken at 6 - $\mathrm{h}$ intervals starting when the largest follicle reached $\geq 8.0 \mathrm{~mm}$. This was just before expected deviation at $8.5 \mathrm{~mm}$ (Ginther et al. 1996). Blood sampling every $6 \mathrm{~h}$ continued until $36 \mathrm{~h}$ after the next ovulation.

\section{Definitions and experimental groups}

The three largest follicles at the ultrasound examination just before a follicle ovulated were designated F1, F2 and F3, according to decreasing diameter. Follicular wave emergence was defined retrospectively as occurring when F1 was $\geq 4.0 \mathrm{~mm}$. A dominant follicle was defined as one that reached $\geq 10 \mathrm{~mm}$ (Kulick et al. 2001, Lopez et al. 2005). In heifers that developed one dominant follicle, the beginning of deviation was based on inspection of the data profiles of follicle diameters for each heifer and was defined as the beginning of a greater diameter difference between the two largest follicles between successive ultrasound examinations as described (Ginther et al. 1997). In heifers that developed two dominant follicles, the beginning of deviation was clarified when indicated by comparing the diameter changes between F1 and F3 (Kulick et al. 2001, Acosta et al. 2005). When the beginning of deviation was not apparent in a heifer, the mean diameter of $\mathrm{F} 1$ at deviation within the group was used to represent deviation in that heifer. This occurred in 4 out of 12 single and 3 out of 8 double ovulators. All end points involving ovulation were related to the first ovulation in the double ovulators. The examination $12 \mathrm{~h}$ before ovulation was used to determine diameter of the preovulatory follicle. Discrete end points were length of the interovulatory interval and intervals from follicular emergence to follicular deviation, peak of the $\mathrm{LH}$ surge to ovulation, beginning of deviation to peak of the $\mathrm{LH}$ surge, and largest diameter of F1 to ovulation. Follicular growth rate was calculated for $\mathrm{F} 1$ and F2 from the total and daily diameter increases between discrete events.

The pre-ovulatory and periovulatory FSH surges were defined as the surges temporally related to the LH surge and to ovulation respectively, as described (Haughian et al. 2004). The first nadir for an FSH surge was the lowest value preceding the progressive increase in concentrations. The second nadir for the pre-ovulatory surge was the same as the first nadir of the periovulatory surge and was the lowest value between the two FSH surges. Concentrations of FSH and time of occurrence of nadirs and peaks were compared among groups.

\section{Blood samples and hormone assays}

Blood samples from the coccygeal vein were collected into heparinised tubes and centrifuged ( $1500 \mathrm{~g}$ for $10 \mathrm{~min}$ ) and plasma was separated and stored at $-20^{\circ} \mathrm{C}$ until assayed. All plasma samples were assayed for $\mathrm{LH}$ and $\mathrm{FSH}$. However, $\mathrm{E}_{2}$ determinations were done on samples collected every $12 \mathrm{~h}$ from 48-12 $\mathrm{h}$ before the peak of the LH surge and then on samples collected every $6 \mathrm{~h}$ until $18 \mathrm{~h}$ after the peak of $\mathrm{LH}$. Concentrations of $\mathrm{LH}$ and FSH were measured by validated RIAs for cattle (Bolt \& Rollins 1983, Bolt et al. 1990) with modifications as reported for $\mathrm{LH}$ (Ginther et al. 1999) and FSH (Adams et al. 1992) in our laboratory. For LH assay, USDA-bLHB-6 was used for iodination and the reference standard, and USDA-309-684P was used as the primary antiserum. For FSH assay, USDA-bFSH-I-2 (AFP-5318C) was used for iodination and the reference standard, and NIDDK-anti-oFSH-1 was used as the primary antiserum. The standards and antibodies were purchased from A F Parlow (National Hormone and Pituitary Program, Torrance, CA, USA). Plasma concentrations of $E_{2}$ were measured as described and validated in our laboratory (Siddiqui et al. 2009), using a commercially available RIA kit (Double Antibody Estradiol: Diagnostics Products Corporation, Los Angeles, CA, USA). The intra-and interassay coefficients of variation and mean sensitivity respectively, were $9.1 \%, 5.2 \%$ and $0.1 \mathrm{ng} / \mathrm{ml}$ for $\mathrm{LH} ; 6.1 \%, 8.0 \%$, and $0.02 \mathrm{ng} / \mathrm{ml}$ for $\mathrm{FSH}$; and $14.1 \%, 7.7 \%$ and $0.1 \mathrm{pg} / \mathrm{ml}$ for $\mathrm{E}_{2}$.

\section{Statistical analyses}

Follicle diameter and hormone concentrations were divided into two data sets, one normalised (hour 0 ) to the beginning of deviation and encompassing -24 or -12 to $24 \mathrm{~h}$ and the second normalised (hour 0 ) to the peak of $\mathrm{LH}$ and encompassing -24 to $24 \mathrm{~h}$. For hormone data, suspected outliers were challenged using Dixon's outlier test (Kanji 1993). Statistical outliers were found for 4 out of 307 observations (1.3\%) for LH and 5 out of 307 observations (1.6\%) for $\mathrm{FSH}$ and were excluded from further analysis. In order to verify the normality distribution, the data for all analyses were examined using the Shapiro-Wilk test and transformed to natural logarithms or ranks when indicated. Data for follicle diameter and hormone concentration were analyzed by SAS MIXED procedure (version 9.1.3, SAS Institute Inc., Cary, NC, USA) for main effects of group and time (hour) and their interaction, using a REPEATED statement to account for sequential measurements. Calculated end points for time intervals and follicular growth 
rates were analyzed by SAS GLM procedure for main effect of group. Differences between two means were evaluated by Student's $t$-test. Differences among more than two means (F1, F2, and F3 within a group) were further analyzed by Duncan's multiple-range test. The significant probability level adopted was $5 \%$, and values $>5 \%$ to $\leq 10 \%$ were considered as approaching significance. Data are presented as the mean \pm s.E.M. unless otherwise indicated.

\section{Declaration of interest}

The authors declare that there is no conflict of interest that would prejudice the impartiality of this scientific work.

\section{Funding}

Supported by the Eutheria Foundation, Cross Plains, WI, USA (Project H1-MP-07).

\section{Acknowledgements}

The authors thank Pfizer Animal Health, New York City, for a gift of Lutalyse (prostaglandin $F_{2 \alpha}$ ), Reno $\mathrm{R}$ de Araújo and Celina M Checura for technical assistance and Fabyano F Silva for statistical assistance.

\section{References}

Acosta TJ, Beg MA \& Ginther OJ 2005 Effects of modified FSH surges on follicle selection and codominance in heifers. Animal Reproduction 2 28-40.

Adams GP, Matteri RL, Kastelic JP, Ko JCH \& Ginther OJ 1992 Association between surges of follicle-stimulating-hormone and the emergence of follicular waves in heifers. Journal of Reproduction and Fertility 94 177-188.

Adams GP, Jaiswal R, Singh J \& Malhi P 2008 Progress in understanding ovarian follicular dynamics in cattle. Theriogenology $6972-80$.

Aerts JMJ \& Bols PEJ 2009 Ovarian follicular dynamics. A review with emphasis on the bovine species. Part II: antral development, exogenous influence and future prospects. Reproduction in Domestic Animals [in press]. DOI: 10.1111/j.1439-0531.2008.01298.x.

Araujo RR \& Ginther OJ 2009 Vascular perfusion of reproductive organs in pony mares and heifers during sedation with detomidine or xylazine. American Journal of Veterinary Research 70 141-148.

Beg MA \& Ginther OJ 2006 Follicle selection in cattle and horses: role of intrafollicular factors. Reproduction 132 365-377.

Beg MA, Meira C, Bergfelt DR \& Ginther OJ 2003 Role of oestradiol in growth of follicles and follicle deviation in heifers. Reproduction $\mathbf{1 2 5}$ 847-854.

Bergfelt DR, Lightfoot KC \& Adams GP 1994 Ovarian synchronization following ultrasound-guided transvaginal follicle ablation in heifers. Theriogenology 42 895-907.

Bergfelt DR, Smith CA, Adams GP \& Ginther OJ 1997 Surges of FSH during the follicular and early luteal phases of the estrous cycle in heifers. Theriogenology 48 757-768.

Bergfelt DR, Kulick LJ, Kot K \& Ginther OJ 2000 Follicular and hormonal response to experimental suppression of FSH during follicle deviation in cattle. Theriogenology 54 1191-1206.

Bleach ECL, Glencross RG, Feist SA, Groome NP \& Knight PG 2001 Plasma inhibin A in heifers: relationship with follicle dynamics, gonadotropins, and steroids during the estrous cycle and after treatment with bovine follicular fluid. Biology of Reproduction 64 743-752.

Bodensteiner KJ, Kot K, Wiltbank MC \& Ginther OJ 1996 Synchronization of emergence of follicular waves in cattle. Theriogenology 45 1115-1126.
Bolt DJ \& Rollins R 1983 Development and application of a radioimmunoassay for bovine follicle-stimulating hormone. Journal of Animal Science 56 146-154.

Bolt DJ, Scott V \& Kirakofe GH 1990 Plasma FSH and LH after estradiol, norgestromet and $\mathrm{GnRH}$ treatment in ovariectomized beef heifers. Animal Reproduction Science 23 263-271.

Echternkamp SE, Spicer LJ, Gregory KE, Canning SF \& Hammond JM 1990 Concentrations of insulin-like growth factor-I in blood and ovarian follicular fluid of cattle selected for twins. Biology of Reproduction 43 8-14.

Echternkamp SE, Roberts AJ, Lunstra DD, Wise T \& Spicer LJ 2004 Ovarian follicular development in cattle selected for twin ovulations and births. Journal of Animal Science 82 459-471.

Engelhardt H, Walton JS, Miller RB \& King GJ 1989 Estradiol-induced blockade of ovulation in the cow: effects on luteinizing hormone release and follicular fluid steroids. Biology of Reproduction 40 1287-1297.

Fortune JE, Rivera GM, Evans AC \& Turzillo AM 2001 Differentiation of dominant versus subordinate follicles in cattle. Biology of Reproduction 65 648-654.

Gastal EL, Gastal MO \& Ginther OJ 2006 Relationships of changes in B-mode echotexture and colour-doppler signals in the wall of the preovulatory follicle to change in systemic oestradiol concentrations and the effects of human chorionic gonadotropin in mares. Reproduction 131 699-709.

Gibbons JR, Wiltbank MC \& Ginther OJ 1997 Functional interrelationships between follicles greater than $4 \mathrm{~mm}$ and the follicle-stimulating hormone surge in heifers. Biology of Reproduction 57 1066-1073.

Ginther OJ 1992 Reproductive Biology of the Mare, Basic and Applied Aspects, edn 2. Cross Plains, WI, USA: Equiservices Publishing.

Ginther OJ 1998 Ultrasonic Imaging and Animal Reproduction. Book 3. Cattle, Cross Plains, WI, USA: Equiservices Publishing.

Ginther OJ \& Almamun M 2009 Increased frequency of double ovulations following induction of luteolysis with exogenous prostaglandin $\mathrm{F}_{2 \alpha}$. Journal of Equine Veterinary Science [in press].

Ginther OJ, Wiltbank MC, Fricke PM, Gibbons JR \& Kot K 1996 Selection of the dominant follicle in cattle. Biology of Reproduction $\mathbf{5 5}$ 1187-1194.

Ginther OJ, Kot K, Kulick LJ \& Wiltbank MC 1997 Emergence and deviation of follicles during the development of follicular waves in cattle. Theriogenology 48 75-87.

Ginther OJ, Bergfelt DR, Kulick LJ \& Kot K 1999 Selection of the dominant follicle in cattle: establishment of follicle deviation in less than 8 hours through depression of FSH concentrations. Theriogenology $\mathbf{5 2}$ 1079-1093.

Ginther OJ, Bergfelt DR, Beg MA \& Kot K 2001 Follicle selection in cattle: role of luteinizing hormone. Biology of Reproduction 64 197-205.

Ginther OJ, Beg MA, Donadeu FX \& Bergfelt DR 2003 Mechanism of follicle deviation in monovular farm species. Animal Reproduction Science 78 239-257.

Ginther OJ, Gastal EL, Rodrigues BL, Gastal MO \& Beg MA 2008 Follicle diameters and hormone concentrations in the development of single versus double ovulations in mares. Theriogenology 69 583-590.

Ginther OJ, Jacob JC, Gastal MO, Gastal EL \& Beg MA 2009 Development of one vs multiple ovulatory follicles and associated systemic hormone concentrations in mares. Reproduction in Domestic Animals $\mathbf{4 4}$ 441-449.

Gong JG, Bramley TA, Gutierrez CG, Peters AR \& Webb R 1995 Effects of chronic treatment with a gonadotrophin-releasing hormone agonist on peripheral concentrations of $\mathrm{FSH}$ and $\mathrm{LH}$, and ovarian function in heifers. Journal of Reproduction and Fertility 105 263-270.

Haughian JM, Ginther OJ, Kot K \& Wiltbank MC 2004 Relationships between FSH patterns and follicular dynamics and the temporal associations among hormones in natural and $\mathrm{GnRH}$-induced gonadotropin surges in heifers. Reproduction 127 23-33.

Hobson WC \& Hansel W 1972 Plasma LH levels after ovariectomy, corpus luteum removal and estradiol administration in cattle. Endocrinology 91 185-190.

Jacob JC, Gastal EL, Gastal MO, Carvalho GR, Beg MA \& Ginther OJ 2009 Follicle deviation in ovulatory follicular waves with one or two dominant follicles in mares. Reproduction in Domestic Animals $\mathbf{4 4}$ 248-254.

Kanji GK 1993100 Statistical Tests. London: Sage Publications. 
Kulick LJ, Kot K, Wiltbank MC \& Ginther OJ 1999 Follicular and hormonal dynamics during the first follicular wave in heifers. Theriogenology $\mathbf{5 2}$ 913-921.

Kulick LJ, Bergfelt DR, Kot K \& Ginther OJ 2001 Follicle selection in cattle: follicle deviation and codominance within sequential waves. Biology of Reproduction 65 839-846.

Lambalk CB, Boomsa DI, Boer LD, De Koning CH, Schoute E, Popp-Snijders C \& Schoemaker J 1998 Increased levels and pulsatility of follicle stimulating hormone in mothers of hereditary dizygotic twins. Jorunal of Clinical Endocrinology and Metabolism 83 481-486.

Lopez H, Sartori R \& Wiltbank MC 2005 Reproductive hormones and follicular growth during development of one or multiple dominant follicles in cattle. Biology of Reproduction 72 788-795.

Lopez-Gatius F, Lopez-Bejar M, Fenech M \& Hunter RHF 2005 Ovulation failure and double ovulation in dairy cattle: risk factors and effects. Theriogenology 63 1298-1307.

Mann GE, Robinson RS \& Hunter MG 2007 Corpus luteum size and function following single and double ovulations in non-lactating dairy cows. Theriogenology 67 1256-1261.

Martin TL, Fogwell RL \& Ireland JJ 1991 Concentrations of inhibins and steroids in follicular-fluid during development of dominant follicles in heifers. Biology of Reproduction 44 693-700.

McNatty KP, Heath DA, Henderson KM, Lun S, Hurst PR, Ellis LM, Montgomery GW, Morrison L \& Thurley DC 1984 Some aspects of thecal and granulosa-cell function during follicular development in the bovine ovary. Journal of Reproduction and Fertility 72 39-53.

Mihm M \& Evans AC 2008 Mechanism of dominant follicle selection in monovulatory species: a comparison of morphological, endocrine and intraovarian events in cows, mares and women. Reproduction in Domestic Animals 43 48-56.
Miller KF, Wesson James A \& Ginther OJ 1981 Interaction of estradiol and a nonsteroidal follicular fluid substance in the regulation of gonadotropin secretion in the mare. Biology of Reproduction 24 354-358.

Mussard ML, Burke CR, Behke EJ, Gasser CL \& Day ML 2007 Influence of premature induction of a luteinizing hormone surge with gonadotropinreleasing hormone on ovulation, luteal function, and fertility in cattle. Journal of Animal Science 85 937-943.

Pierson RA \& Ginther OJ 1988 Ultrasonic-imaging of the ovaries and uterus in cattle. Theriogenology 29 21-37.

Sartori R, Fricke PM, Ferreira JCP, Ginther OJ \& Wiltbank MC 2001 Follicular deviation and acquisition of ovulatory capacity in bovine follicles. Biology of Reproduction 65 1403-1409.

Siddiqui MAR, Gastal EL, Gastal MO, Almamun M, Beg MA \& Ginther OJ 2009 Relationship of vascular perfusion of the wall of the preovulatory follicle to in vitro fertilisation and embryo development in heifers. Reproduction 137 689-697.

Sirois J \& Fortune JE 1988 Ovarian follicular dynamics during the estrouscycle in heifers monitored by real-time ultrasonography. Biology of Reproduction 39 308-317.

Webb R \& Campbell BK 2007 Development of the dominant follicle: mechanisms of selection and maintenance of oocyte quality. Society of Reproduction and Fertility Supplement 64 141-163.

Wiltbank MC, Fricke PM, Sangsritavong S, Sartori R \& Ginther OJ 2000 Mechanisms that prevent and produce double ovulations in dairy cattle. Journal of Dairy Science 83 2998-3007.

Received 6 March 2009

First decision 7 April 2009

Accepted 15 June 2009 